\title{
Understanding of Loyalty Programs' Participation Rules
}

\author{
A Compreensão das Regras de Participação em Programas de Fidelidade
}

La Comprensión de las Normas de Participación de los Programas de Fidelización

\author{
Lunie Imamura de Lima ${ }^{1}$ \\ Pedro José Steiner Neto ${ }^{2}$
}

Received on August 22, 2012 / Approved on November 6, 2013

Responsible Editor: João Maurício Gama Boaventura, Dr.

Evaluation Process: Double Blind Review

\begin{abstract}
The understanding of loyalty programs' participation rules is tested in this study within three experiments conducted to check the influence of the regulatory focus, prize type, and of the interaction of both. Experiment 1 shows that the regulatory focus somehow affects the degree of understanding of the programs' rules. Experiment 2 shows that the prize type also affects the degree of understanding of the programs' rules. And, at last, it is shown that Experiment 3 does not corroborate the hypothesis of the interaction of those variables on the degree of understanding of the programs' rules. The conclusion is that the understanding of loyalty programs' rules is higher to individuals in the state of prevention and of receiving utilitarian award, and that, however, there is no influence of their interaction. The study contributes to corroborate
\end{abstract}

the matching effect and the hypotheses of the regulatory focus theory on the consumer behavior, also proposing managerial implications to loyalty programs' managers.

Keywords: Promotion. Prevention. Hedonic. Utilitarian. Redemption rules.

\section{RESUMO}

A compreensão das regras de participação em programas de fidelidade é testada neste estudo a partir de três experimentos conduzidos para averiguar a influência do foco regulatório, o tipo de premiação e o efeito de interação entre eles. $\mathrm{O}$ Experimento 1 demonstra que o foco regulatório tem impacto sobre o nível de compreensão das regras dos programas. O Experimento 2 nos mostra que o tipo de premiação também tem impacto sobre o nível de compreensão

1. Doctor in Administration from the Federal University of Paraná (UFPR). Professor of the Curitiba University Center. [lunielima@yahoo.com.br]

2. Doctor in Administration from the University of São Paulo (USP). Professor of the Federal University of Paraná (UFPR). [pedrosteiner@ufpr.br]

Authors' address: Rua Pref. Lothario Meissner, 632 - Jardim Botânico - CEP 80210-170 - Curitiba, PR - Brazil 
das regras dos programas. E, finalmente, prova que o Experimento 3 não permite corroborar a hipótese que prevê a interação entre aquelas variáveis sobre o nível de compreensão das regras dos programas. Conclui-se que a compreensão das regras dos programas de fidelidade será maior para indivíduos no estado de prevenção e de recebimento de premiação utilitária e que, no entanto, não há influência da interação entre estes. O estudo contribui para corroborar o efeito de matching e hipóteses da teoria do foco regulatório sobre o comportamento do consumidor e propóe, ainda, implicaçóes gerenciais para administradores de programas de fidelidade.

Palavras-chave: Promoção. Prevenção. Hedônico. Utilitário. Regras de resgate.

\section{RESUMEN}

El entendimiento de las reglas de participación de los programas de fidelización se prueba en este estudio a partir de tres experimentos llevados a cabo para investigar la influencia del enfoque regulador, el tipo de premio y el efecto de la interacción entre ellos. El Experimento 1 muestra que el enfoque regulador impacta en el nivel de comprensión de las reglas del programa. El segundo experimento muestra que el tipo de premio también afecta el nivel de comprensión de las reglas del programa. Finalmente, el tercer experimento no confirma la hipótesis de la interacción entre esas variables en el nivel de comprensión de las reglas del programa. De ello se desprende que la comprensión de las reglas de participación de los programas de fidelización será mayor para los individuos en la prevención $y$ al recibir los premios utilitarios, aunque no está influenciada por la interacción entre ellos. El estudio ayuda a confirmar el efecto de matching y los supuestos de la teoría del enfoque regulador del comportamiento del consumidor. Asimismo, propone implicaciones de gestión para los gestores de los programas de fidelización.

Palabras clave: Promoción. Prevención. Hedónico. Utilitario. Reglas de rescate.

\section{INTRODUCTION}

Loyalty programs perform a key role in the relationship marketing strategies performed in different sectors of the economy, being a core tool to maintain the relationship with customers. Evidences that it is more costly to invest in acquiring new customers than in keeping the existing ones, in addition to the assumption that some particular consumers are more profitable than others, corroborate the idea of these programs creation, which aim both to prize the loyalty as well as to create barriers regarding the costs of changing the supplier on the part of the consumer (O'BRIEN, JONES, 1995).

A survey conducted by Bretzke Consultoria (2005) has identified that $40 \%$ of the eligible customers of loyalty programs do not adhere to them, $60 \%$ of those that take part in programs do not recognize their loyalty benefits, $81 \%$ of customers entitled to benefits do not ask for them, $70 \%$ of those that have already used the benefits were not fully satisfied, and $60 \%$ of companies do not obtain potential returns in reputation, profitability and sales. Market information of such nature increases the questioning about these relationship marketing practices.

Factors such as who are the customers eligible to these programs, what is the ideal promotion permanence period, or even which concept the program promoting company should adopt to attract and maintain its customers, are still unanswered, and suggest that the subject should be further studied in deep. For instance, one of the main problems pointed out by past surveys are the loyalty programs' participation rules (O'BRIEN, JONES, 1995; DREZE, HOCH, 1998; HSEE et al., 2003; SOMAN, 1998), which might affect the participants' intention to enter and remain in such programs (BOOTZIN et al., 1991).

This study has the aim of evaluating the understanding of the point accumulation and award redemption rules on the part of loyalty programs' participants. To attain such goal, three experiments are conducted to test the relation between the program focus, the type of award 
offered, the interaction between these, and the understanding of the programs' participation rules. It also proposes the use of a study object (Loyalty Programs) still not used to test the effects of the regulatory focus theory, as a way to progress the results found on this theory.

\section{THEORETICAL FOUNDATIONS}

\section{I Promotion focus versus prevention focus}

The Theory of the Regulatory Focus, whose pioneer is E. Tory Higgins (1987; 1997; 1998; 2000; 2002), has been used by various studies on the consumer behavior, and is already showing results that are consistent with the behavioral patterns adopted by consumers during the stages of the purchase decision process. For instance, Pham and Avnet (2004) have shown that individuals with promotion focus shall search for options signaling their positive aspects, while the individuals with prevention focus shall search for options signaling their negative aspects, during the information search process. Furthermore, information regarding gains versus no gains will have a bigger weight under the promotion focus, while information regarding losses versus no losses will have a bigger weight under the prevention focus (ZHOU, PHAM, 2004; LEE, AAKER, 2004). At last, information regarding the "eagerness" will have more power to influence individuals with promotion focus, while the information regarding "alertness" will have more power to influence individuals with prevention focus (CESARIO, GRANT, HIGGINS, 2004; SPIEGEL, GRANTPILLOW, HIGGINS, 2004).

Another important aspect found in previous studies on the effects of the regulatory focus was the existence of a basic principle of the matching type to appraise objects under different regulatory focuses. In such case, the information on attributes has a bigger weight when its contents are compatible with the individual regulatory state. Hence, attractive (non attractive) alternatives regarding the dimensions of the promotion focus will be appraised in a more favorable (less favorable) way when the promotion state is activated - it will likewise occur in regard to the prevention focus (SAFER, 1998; AAKER, LEE, 2001; WANG, LEE, 2006).

In view of the aforementioned, we suggest that, in loyalty programs, the regulatory focus adopted by the program also affects the choices and appraisals done by their participant members. Thus, we suggest that, for instance, in view of a situation of program rules appraisal, different regulatory focuses result in different understanding perceptions of such rules. Therefore, based on the characteristics of "eagerness" (CESARIO, GRANT, HIGGINS, 2004; SPIEGEL, GRANTPILLOW, HIGGINS, 2004) and on the focus on gains versus no gains of individuals in the promotion state (PHAM, AVNET, 2004; ZHOU, PHAM, 2004; LEE, AAKER, 2004), we propose that the focus of such participants of loyalty programs falls on the desired prize, or in the attainment of the desired goal, and not on the restrictions imposed by the program. On the other hand, based on the characteristics of "alertness" (CESARIO, GRANT, HIGGINS, 2004; SPIEGEL, GRANT-PILLOW; HIGGINS, 2004) and on the focus on losses versus no losses of individuals in the prevention state (PHAM, AVNET, 2004; ZHOU, PHAM, 2004; LEE, AAKER, 2004), we propose that the focus of such participants of loyalty programs falls on the restriction imposed by the program, rather than on the desired prize. Therefore, the first hypotheses suggested in this study are:

$\mathrm{H}_{1}$ : The regulatory focus adopted by the loyalty program will affect the program rules understanding, so that:

$\mathrm{H}_{1 \mathrm{a}}$ : When the regulatory focus of the loyalty program is a promotion one, its participants shall show a lower understanding of the program rules.

$\mathrm{H}_{1 \mathrm{~b}}$ : When the regulatory focus of the loyalty program is a prevention one, its participants shall show a higher understanding of the program rules. 


\subsection{Hedonic prize versus utilitarian prize}

Nunes and Drèze (2006, p. 129) point out that "to be attractive, a loyalty program should encourage the redemption of prizes; only then they will be really attractive to consumers". The authors also point out that, for the consumers, the accumulation of points and the redemption of prizes are perhaps the most memorable components of their participations in loyalty programs.

Two types of prizes frequently offered in loyalty programs are those evoking hedonic and utilitarian benefits. The hedonic value of prizes offered by such programs would be associated to non-instrumental, experience-related, emotional and personal gratification-related benefits (HIRSCHMAN, HOLLBROOK, 1982); to items evoking the "luxury" status (KIVETZ, SIMONSON, 2002a; 2002b; STRAHILEVITZ, MYERS, 1998), and which have a strong emotional appeal (ROTTENSTREICH, HSEE, 2001; SCHWARZ, CLORE, 1983). On the other hand, the utilitarian value of prizes offered by those programs would be more associated to instrumental, functional and cognitive benefits, and which add value to the consumers by providing means to achieve their desired purposes (HIRSCHMAN, HOLBROOK, 1982).

Pham and Higgins (2005) show that the information on attributes related to hedonic and aspirational benefits (such as luxury and personal and aesthetic gratification) get a bigger evaluating weight on the promotion regulatory state, while the information on attributes related to utilitarian and necessity benefits (such as security and protection) get a bigger evaluating weight on the prevention regulatory state. Safer (1998) also concludes that when choosing between products with high scores in the "luxury" dimension, although with low scores in the "protection" dimension (such as car with leather seats and standard braking system), and products with low scores in the "luxury" dimension, but with high scores in the "protection" dimension (such as a car with advanced braking system, and standard seats), consumers in the promotion regulatory state would tend to choose the first products, while the consumers in the prevention regulatory state would choose the last ones.

Therefore, we suggest that, in loyalty programs, the prize offered by the program also affects the choices and appraisals done by their participant members. Thus, the hedonic prize should induce the program's participants to the promotion regulatory state, which will result in the appraisal of the program's rules under such focus, once again with the focus on gains versus no gains, and with characteristics of "eagerness". On the other hand, the utilitarian prize should induce the program's participants to the prevention regulatory state, which will also result in the program's rules appraisal under such focus, i.e., with focus on losses versus no losses, and with the characteristics of the "alertness". Based on the above discussion, the next hypotheses suggested in this study are as follows:

$\mathrm{H}_{2}$ : The type of prize offered by the loyalty program will affect the understanding of the program's rules, so that:

$\mathrm{H}_{2 \mathrm{a}}$ : When the prize is of the hedonic type, its participants should show a smaller understanding of the program's rules. $\mathrm{H}_{2 \mathrm{~b}}$ : When the prize is of the utilitarian type, its participants should show a higher understanding of the program's rules.

\subsection{The rules of redemption of the loyalty programs}

The design or concept of a loyalty program is one of the most discussed topics in the literature that addresses the customers' loyalty schemes. It is known that the program has the power to influence both the motivation and the behavior of point redemption by its participants (O'BRIEN, JONES, 1995). The attainment of prizes in such programs requires a series of sacrifices by its participants - in most cases, such 
sacrifices last for a long period of time, and the prize is attained only after their accomplishment (DRĖZE, HOCH, 1998; SOMAN, 1998; HSEE et al., 2003). Past research has identified the main difficulties faced by the loyalty program participants, showing the accumulation and prize redemption rules understanding as one of the key factors to motivate their permanence in the loyalty scheme.

Lewis (2004) defends that the loyalty scheme adopted by a company should have a structure capable of motivating the program's participants to visualize the purchase act as a sequence of interconnected decisions that will result in a prize offered by the company, instead of mere economic transactions isolated in time and space. We observe that the scoring rules, the periods of prize redemption and the restrictions to such redemptions are not always clear to the loyalty programs' participants.

For instance, Sharp and Sharp (1997) have seen that most of the participants of the loyalty programs does not fully understand the point redemption rules to attain prizes, and this strongly reduces the motivation to redeem prizes in such programs. The program's participant many times does not have the knowledge of all the clauses included in the company's contract determining the details of the prize redemption.

Once again, based on the matching principle (AAKER, LEE, 2001; WANG, LEE, 2006) that suggests the compatibility between information, objects and situations appraised under the promotion or prevention focus, it is shown that the understanding of the loyalty program rules will be a function of the regulatory focus adopted by the program, and of the type of prize offered by it. Thus, we start with the hypothesis that individuals allocated in a promotion scenario and who received a prize compatible with this focus, i.e., a hedonic prize, should have a higher degree of understanding of the loyalty program rules, against those that were allocated in the same scenario and have received an incompatible prize. Therefore, we expect to observe this effect for individuals who were allocated in the prevention scenario, and have received a prize compatible with such focus, i.e., a utilitarian prize. Therefore, the last hypotheses suggested in this study are:

$\mathrm{H}_{3}$ : The interactive effect of the regulatory focus adopted by the loyalty program, and the type of prize offered by the loyalty program, will affect the understanding of the program's rules, so that:

$\mathrm{H}_{3 \mathrm{a}}$ : When the regulatory focus of the loyalty program is compatible with the type of prize offered, its participants shall show a higher understanding of the program rules.

$\mathrm{H}_{3 \mathrm{~b}}$ : When the regulatory focus of the loyalty program is incompatible with the type of prize offered, its participants shall show a lower understanding of the program rules.

\section{METHODOLOGY}

This study is classified as a conclusivecausal of experimental nature study. Causal studies try to quantitatively enunciate the dependency relations between the variables to check the causal relation hypotheses (SHADISH, COOK, CAMPBELL, 2002). According to such authors, it can also be described as an attempt to explain the variability of one or more phenomena of interest (dependent variables), assigning them with their presumed causes (independent variables).

Experimental studies have three different features: random allocation of the research subjects in different levels of an independent variable, manipulation of the levels of the independent variable and control of exogenous variables. The main decisions to be made in the experiment regard to the clear definition of the levels of the independent variable, how they will be manipulated, how and when they will be exposed to the study participants (GOODWIN, 2007).

The rationale to select the experimental method is mainly for it allowing the investigation 
of certain conditions supposed to cause certain effects (KEPPEL, WICKENS, 2004), i.e., through the manipulation of a independent variable its effect on a dependent variable can be checked.

The technique of data analysis used in this work was the Variance Analysis (One-way ANOVA - an independent variables and the Two-way ANOVA - two or more independent variables). A Variance Analysis tries to check whether there are significant differences between the averages, and whether the factors exert some influence on some dependent variable. Thus, it allows the comparison of various groups at the same time, either having quantitative or qualitative origin, but with a necessarily continuous dependent variable (Goodwin, 2007). The level of significance adopted in all the hypotheses tests conducted in this research was defined as 0.05 .

\section{EXPERIMENTS}

\section{I Experiment 1}

\subsubsection{Procedures}

The first experiment in this study was the type 2 experiment (regulatory focus: promotion vs. prevention) by 1 (understanding of rules) between subjects design, and has tested the effect of the regulatory focus adopted by the loyalty program on the understanding of the program's rules. We started from the hypothesis that the individuals allocated in the promotion scenario should show a smaller degree of understanding of the rules in comparison to those allocated in the prevention scenario. Thus, Experiment 1 tests the first hypothesis of this research.

Sixty nine (69) graduate students (out of which $53.6 \%$ were women, with average age between 18 and 25 years), of a university in southern Brazil, were randomly allocated in two experimental conditions (promotion vs. prevention). The sample distribution is shown in Table 1. The research participants were previously warned by the discipline professor that a student would be present at the scheduled date to apply a questionnaire that would be the base for her doctor's degree thesis. Thus, a period of 15 minutes was reserved at the end of their first class to take part in the study. Those not willing to take part in the survey were released for the break.

TABLE 1 - Sample distribution in Experiment 1

\begin{tabular}{ccc}
\hline \multicolumn{3}{c}{ Regulatory focus } \\
\hline Promotion & Prevention & Total \\
36 & 33 & 69 \\
\hline
\end{tabular}

Source: the authors, data collection 2012.

Students were informed that they would take part of a research about relationship or loyalty programs and that, for such a purpose, they would receive a printed material with a text with the description of a loyalty program, which should be carefully read. The condition to take part of the study was that they should be already actively participating of at least one loyalty program. The loyalty programs were introduced, in a written and printed manner (see the following table), in a text of approximately 100 words. For each experimental condition, a text with promotion or prevention focus was used, in order to activate the regulatory focus. After the activation of the regulatory focus of the loyalty programs, the participants showed how much they had understood of the programs participation rules, in a Likert scale of seven points, in which $1=\mathrm{I}$ didn't understand anything, $7=\mathrm{I}$ understood everything. At the end, they were thanked for their participation in the research and were dismissed. 


\begin{tabular}{|c|c|}
\hline Promotion Focus & Prevention Focus \\
\hline $\begin{array}{l}\text { Imagine a Loyalty Program of a restaurant offering international } \\
\text { cuisine that invites you to make part of its advantage club. } \\
\text { Becoming a member of our program, you will enjoy exclusive } \\
\text { delicious promotions to the participants, such as reservations for } \\
\text { dinners in special dates (Valentine's Day, Mother/Father's Day); } \\
\text { From } 100 \text { points accumulated in the program (each } \mathrm{R} \$ 1 \text { spent is } \\
\text { equal } 1 \text { point), the participants might already choose a delicious } \\
\text { dessert of the house (a red fruits petit gateau) or a bonus in the } \\
\text { amount of R } \$ 20 \text {. Make part of our advantage club and start to } \\
\text { enjoy such benefits right now! }\end{array}$ & $\begin{array}{l}\text { Imagine a Loyalty Program of a supermarket chain offering a } \\
\text { larger variety of products at unbeatable prices that is inviting } \\
\text { you to make part of its advantage club. } \\
\text { By becoming a member of our program, you will enjoy exclusive } \\
\text { can't miss promotions to the participants, such as discounts in } \\
\text { products and free delivery services. From } 100 \text { points accumulated } \\
\text { in the program (each } R \$ 1 \text { spent is equal } 1 \text { point), the participants } \\
\text { might already choose between a delicious basked of wines and } \\
\text { chocolates, or a bonus in the amount of } R \$ 20 \text {. Make part of our } \\
\text { advantage club and start to enjoy such benefits right now! }\end{array}$ \\
\hline
\end{tabular}

CHART 1 - Experiment 1 Scenarios

Source: the authors, data collection 2012.

\subsubsection{Results}

A pre-test with 30 participants with the same profile of this study was conducted to check the effectiveness of the manipulation of the regulatory focus adopted by the loyalty programs. The participants showed, in a Likert scale of seven points, how much the descriptions of the scenarios would be close to the "aspirations and desires" ( 1 = Not at all, $7=$ Vey close $)$, and "responsibilities and duties" ( $1=$ Not at all, $7=$ Very close $)$. As expected, "aspirations and desires" were more significantly associated to the restaurant's loyalty program $(M=4.01)$ instead of the supermarket's loyalty program $(M=2.89 ; F(1.13)$ $=4.51, p=0.01)$. Similarly, "responsibilities and duties" were more significantly associated to the supermarket's loyalty program $(M=3.67)$, than to the restaurant's loyalty program $(M=2.05$; $F(1.13)=3.51, p=0.00)$.

We expected that the understanding of the loyalty programs' rules, showed by the study participants, was higher for the individuals in the prevention scenario and lower for the individuals in the promotion scenario. A One-way ANOVA was conducted with an independent variable, regulatory focus of the loyalty program, and a dependent variable, understanding of the loyalty program rules. The result showed that the participants in the prevention scenario have actually showed a higher understanding of the loyalty program rules $(M=5.47 ; S . D=1.33)$ than the participants of the promotion scenario $(M=4.00 ; S . D=1.19) ; F(1.68)=23.47$, $p=0.00)$, corroborating the $\mathrm{H}_{1 \mathrm{a}}$ and $\mathrm{H}_{1 \mathrm{~b}}$ hypotheses.

Figure 1 below shows the averages of the understanding of loyalty program's rules for each group.

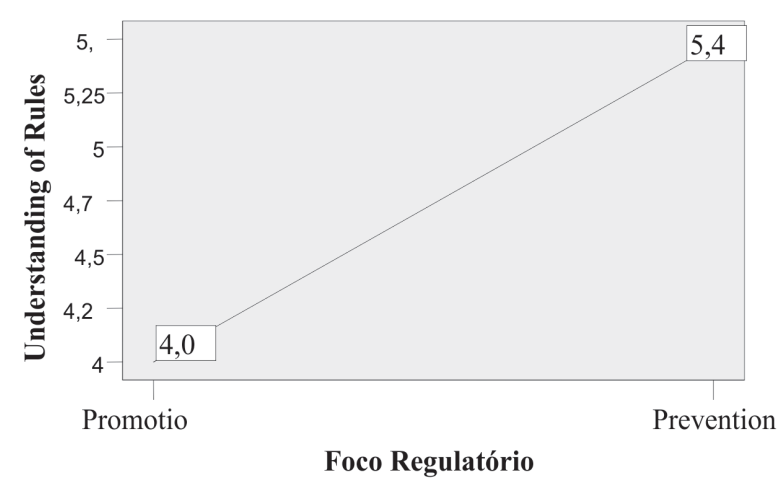

FIGURE 1 - Understanding of rules $\boldsymbol{v}$. Regulatory focus

Source: the authors, data collection 2012.

In view of the aforementioned, the $\mathrm{H}_{1}$ hypothesis could be corroborated. Thus, we suggest that the degree of understanding of loyalty program's rules showed by the study participants would be affected by the regulatory focus, in the sense that those allocated in the prevention scenario $\left(\left(M_{\text {Prevention }}=5.47\right)\right.$ have shown a higher degree of understanding of the rules than those allocated in the promotion scenario $\left(M_{\text {Promotion }}=4.00\right)$.

An alternative explanation for this finding would be that the scenarios used in this experiment (promotion scenario - international cuisine 
restaurant; prevention scenario - supermarket chain) have inflated the results found, due to their nature (service vs. retail). Therefore, we suggest the use of a similar nature scenario in the next experiments.

\subsection{Experiment 2}

\subsubsection{Procedures}

The second experiment, of type 2 (Type of Prize: hedonic vs. utilitarian) by 1 (understanding of the loyalty program's rules) 'between subjects' design, has tested the effect of the type of prize offered by the loyalty program on the understanding of the program's rules. We started from the hypothesis that the individuals receiving the hedonic prize would show a smaller degree of understanding of the rules than the individuals receiving a utilitarian prize. Thus, Experiment 2 tests the second hypothesis of this research, and also addresses the shortcomings of the previous experiment.

One hundred and seventeen (117) graduate students (out of which $51.3 \%$ were women, with average age between 18 and 25 years), of a university in southern Brazil, were randomly allocated in two experimental conditions (hedonic prize $v s$. utilitarian prize). The sample distribution is shown in Table 2. The research participants were previously warned by the discipline professor that a student would be present at the scheduled date to apply a questionnaire that would be the base for her doctor's degree thesis. Thus, a period of 15 minutes was reserved at the end of their first class to take part in the study. Those not willing to take part in the survey were released for the break.

TABLE 2 - Sample distribution in Experiment 2

\begin{tabular}{ccc}
\hline \multicolumn{3}{c}{ Awards } \\
\hline Hedonic & Utilitarian & Total \\
\hline 55 & 62 & 117 \\
\hline
\end{tabular}

Source: Authors, data collection 2012.

The instructions received by the participant students follow the same guidance of Experiment 1. The loyalty programs were introduced, in a written and printed manner, with a text of approximately 100 words describing the same loyalty program scenario (see the following chart). For each experimental condition, a prize representing hedonic or utilitarian benefits was used, just below the text of the loyalty program, and which was depicted by a figure. Then, the same question about the understanding of the program's rules was asked to the participants, utilizing a Likert scale of seven points, where $1=$ I didn't understand anything, 7 = I understood everything. After answering the question, the participants were thanked and dismissed.

\begin{tabular}{|c|c|}
\hline Hedonic Prize & Utilitarian Prize \\
\hline $\begin{array}{l}\text { Imagine a Loyalty Program of a Drugstore chain offering a } \\
\text { large variety of products that is inviting you to make part of } \\
\text { its advantage club. } \\
\text { By becoming a member of our program, you will enjoy exclusive } \\
\text { advantages to the program participants, such as folders with offers } \\
\text { customized according to your preferences, and also advantages in } \\
\text { paying your purchases in installments, in addition to imported } \\
\text { products kits. From } 100 \text { points accumulated in the program (each } \\
\mathrm{R} \$ 1 \text { is equal to } 1 \text { point), the participants can already get a shampoo } \\
\text { and conditioner kit of the American brand John Frieda. Make part } \\
\text { of our advantage club and start to enjoy the benefits right now! }\end{array}$ & $\begin{array}{l}\text { Imagine a Loyalty Program of a Drugstore chain offering a } \\
\text { large variety of products that is inviting you to make part of } \\
\text { its advantage club. } \\
\text { By becoming a member of our program, you will enjoy exclusive } \\
\text { advantages to the program participants, such as folders with offers } \\
\text { customized according to your preferences, and also advantages in } \\
\text { paying your purchases in installments, in addition to imported } \\
\text { products kits. From } 100 \text { points accumulated in the program (each } \\
\mathrm{R} \$ 1 \text { is equal to } 1 \text { point), the participants can already get a coupon } \\
\text { in the amount of } \mathrm{R} \$ 20 \text { to be spent as you like in the drugstore. } \\
\text { Make part of our advantage club and start to enjoy the benefits } \\
\text { right now! }\end{array}$ \\
\hline
\end{tabular}

CHART 2 - Experiment 2 Scenarios

Source: the authors, data collection 2012. 
A pre-test with 30 participants with the same profile of this study was conducted to check the effectiveness of the manipulation of the type of prize offered by the loyalty programs. The participants showed, in a Likert scale of seven points, how much the prizes would be related to "non-instrumental, experience-related and personal gratification-related benefits" ( 1 = Not at all, 7 = Very much), and to "instrumental, functional, benefits, a mean to reach the purposes" ( $1=$ Not at all, $7=$ Very much). As expected, "non-instrumental, experience and personal gratification-related benefits" were more significantly associated to the hedonic prize $(M=4.76)$ than to the utilitarian prize $(M=3.02 ; F(1.13)=5.72, p=0.00)$. Similarly, "instrumental, functional benefits, a mean to reach the purposes" were more significantly associated to the utilitarian prize $(M=5.07)$ than to the hedonic prize $(M=2.36 ; F(1.13)=3.05$, $p=0.03)$.

It was expected that the understanding of the loyalty programs' rules, showed by the study participants, was higher for the individuals that have received the utilitarian prize, and lower for the individuals who have received the hedonic prize. A One-way ANOVA was conducted with an independent variable, type of prize offered by the loyalty program, and a dependent variable, understanding of the loyalty program rules. The result showed that the participants that have received the utilitarian prize have actually showed a higher understanding of the loyalty program rules $(M=4.69 ; S . D=1.49)$ than the participants who have received the hedonic prize $(M=3.81 ; S . D=1.05) ; F(1.11)=8.14, p=0.00)$, corroborating the $\mathrm{H}_{2 \mathrm{a}}$ and $\mathrm{H}_{2 \mathrm{~b}}$ hypotheses.

Figure 2 below shows the averages of the understanding of loyalty program's rules for each group.

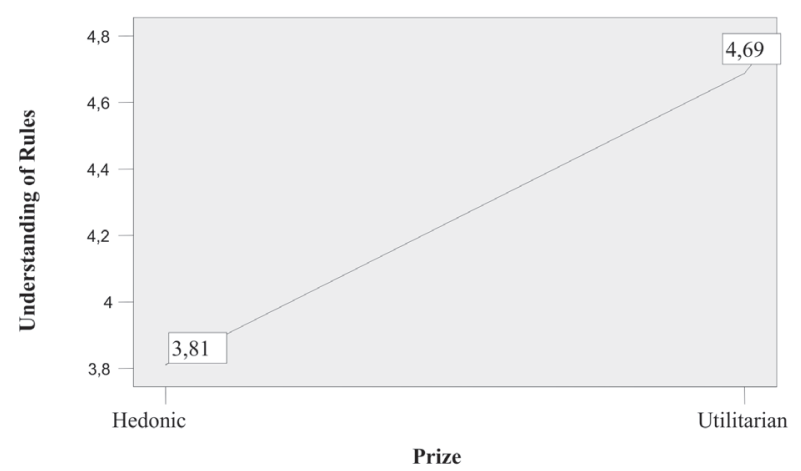

FIGURE 2 - Understanding of rules $\boldsymbol{v} \boldsymbol{s}$. Type of prize

Source: the authors, data collection 2012.

In view of the aforementioned, the $\mathrm{H}_{2}$ hypothesis, that the understanding degree of the loyalty programs' rules showed by the study participants would be affected by the type of prize offered by the loyalty program, is confirmed, in the sense that those receiving the utilitarian prize $\left(M_{\text {Utilitarian }}=4.69\right)$ showed a higher understanding of the rules than those receiving the hedonic prize $\left(M_{\text {Hedonic }}=3.81\right)$.

In this study, the experimental scenario was uniform among the conditions to address the shortcoming identified in the conduction of the previous study. Therefore, only the prize options were manipulated. An alternative explanation for the results found is possibly the fact that the hedonic prize (shampoo and conditioner kit of the John Frieda brand) would have inflated the results, considering that some participants could not check the economic and symbolic value of the brand. This issue is revisited in the next experiment.

\subsection{Experiment 3}

\subsubsection{Procedures}

The third experiment in this study was the type 2 experiment (regulatory focus: promotion vs. prevention) by 2 (type of prize: hedonic vs. utilitarian) between subjects design, and has tested the relation between the regulatory focus adopted 
by the loyalty program and the type of prize offered by the program on the understanding of the rules. We started from the hypothesis that, when prizes compatible with the regulatory focus adopted by the program are offered, i.e., hedonic prize to the promotion focus, and utilitarian prize to the prevention focus, the participants should show a higher degree of understanding of the rules, than when they received prizes incompatible to the program's regulatory focus. Thus, Experiment 3 tests the last hypothesis of this research.

One hundred and forty two (142) graduate students (out of which $53.5 \%$ are women, with average age between 26 and 35 years) of an university in southern Brazil were randomly allocated in four experimental conditions resulting from the combination between the regulatory focus $f$ the loyalty program (promotion vs. prevention), and the type of prize offered (hedonic vs. utilitarian). The sample distribution is shown in Table 3. The research participants were previously warned by the discipline professor that a student would be present at the scheduled date to apply a questionnaire that would be the base for her doctor's degree thesis. Thus, a period of 15 minutes was reserved at the end of their first class to take part in the study. Those not willing to take part in the survey were released for the break.

TABLE 3 - Sample distribution in Experiment 3

\begin{tabular}{cccc}
\hline \multicolumn{4}{c}{ Regulatory focus } \\
\hline Prize & Promotion & Prevention & Total \\
\hline Hedonic & 32 & 36 & 68 \\
Utilitarian & 39 & 35 & 74 \\
Total & 71 & 71 & 142 \\
\hline
\end{tabular}

Source: Authors, data collection 2012.

The instructions received by the participant students follow the same guidance of Experiments 1 and 2 . The loyalty programs were introduced, in a written and printed manner, with a text of approximately 100 words describing the same loyalty program scenario (see the following chart). For each experimental condition, a text with a promotion or prevention focus was used, and a prize of the hedonic or utilitarian type was offered, being depicted by a figure just below the loyalty program text. Then, the same question about the understanding of the program's rules was asked to the participants, utilizing a Likert scale of seven points, where 1 = I didn't understand anything, 7 = I understood everything. After answering the question, the participants were thanked and dismissed.

\begin{tabular}{|c|c|}
\hline Focus & Prevention Focus \\
\hline $\begin{array}{l}\text { Imagine a Loyalty Program of a Movie Theater chain offering } \\
\text { the best national and international premieres of movies that } \\
\text { is inviting you to make part of its advantage club. } \\
\text { By becoming a member of our program, you will enjoy exclusive } \\
\text { promotions and advantages, such as advance purchase of tickets } \\
\text { for previews of featured movies, and delicious kits/combos of } \\
\text { our snack shop. From } 100 \text { points accumulated in the program } \\
\text { (each R } \$ 1 \text { is equal to } 1 \text { point), the participants can already } \\
\text { choose between a soda and popcorn combo, or a bonus to buy a } \\
\text { second ticket. Make part of our advantage club and start to enjoy } \\
\text { them right now! }\end{array}$ & $\begin{array}{l}\text { Imagine a Loyalty Program of Gas Stations chain offering } \\
\text { products and premium services to your car that is inviting } \\
\text { you to make part of its advantage club. } \\
\text { By becoming a member of our program, you will enjoy exclusive } \\
\text { can't miss promotions to the participants, such as discounts in } \\
\text { products and services, and kits especially made to your family. } \\
\text { From } 100 \text { points accumulated in the program (each } \mathrm{R} \$ 1 \text { is equal } \\
\text { to } 1 \text { point), the participants can already choose between a beautiful } \\
\text { thermal bag designed by a fashion designer, or a bonus in the } \\
\text { amount of } \mathrm{R} \$ 20 \text { to be spent with the station's products. Make part } \\
\text { of our advantage club and start to enjoy them right now! }\end{array}$ \\
\hline
\end{tabular}

CHART 3 - Experiment 3 Scenarios

Source: the authors, data collection 2012 . 


\section{$4 \cdot 3 \cdot 2$ Results}

A pre-test with 30 participants with the same profile of this study was conducted to check the effectiveness of the manipulations of the regulatory focus adopted by the loyalty programs and of the prizes offered by them. Thus, the participants showed, in a Likert scale of seven points, how much the descriptions of scenarios would be close to the "aspirations and desires" $(1=$ Not at all, $7=$ Very much $)$ or to the "responsibilities and duties" $(1=$ Not at all, 7 = Very much), and how much the prizes would be related to "non-instrumental, experience and personal gratification related benefits" ( 1 = Not at all, $7=$ Very much), or to "instrumental, functional benefits, mean to attain the purposes" $(1=$ Not at all, $7=$ Very much $)$.

As expected, "aspirations and desires" were more significantly associated to the movie theater loyalty program $(M=4.75)$ than to the gas station loyalty program $(M=3.42 ; F(1.13)=5.76, p=$ $0.00)$. Similarly, "responsibilities and duties" were more significantly associated to the gas station loyalty program $(M=4.26)$ than to the movie theater loyalty program $(M=2.25 ; F(1.13)=3.52$, $p=0.02)$. Also as expected, "non-instrumental, experience and personal gratification related benefits" were more significantly associated to the two hedonic prizes $(M=5.15)$ than to the utilitarian prizes $(M=2,98 ; F(1,89)=3,74$, $p=0,03$ ). In a similar way, "instrumental, functional benefits, mean to attain the purposes" were more significantly associated to the utilitarian prizes $(M=4.25)$ than to the hedonic prizes $(M=2.88 ; F(1.14)=3.75, p=0.00)$.

It was expected that the understanding of the program rules, showed by the study participants, would reflect the compatibility between the program regulatory focus and the prize offered; thus, in the promotion scenario, this should be higher for those receiving the hedonic prize, while in the prevention scenario, this should be higher for those receiving the utilitarian prize.

The Independent Sample's T-Test has shown, once again, that the participants of the prevention scenario had a higher understanding of the loyalty programs' rules $(M=4.81 ; S . D=$ 1.22) than of the promotion scenario participants $(M=3.32 ; S . D=1.26) ; t(142)=-7.20$, $p=0.00$ ), also showing a significant difference for the understanding of the loyalty programs' rules in Experiment 3.

A Two-Way ANOVA was conducted, with the between-subjects variables: regulatory focus of the loyalty program (promotion vs. prevention), and the type of prize offered (hedonic vs. utilitarian), and the average understanding of the loyalty programs' rules as the dependent variable. The results have shown that the main effect of the regulatory focus of the loyalty program on the degree of understanding of the program's rules was significant $(F(1.138)=75.15$, $p=0.00)$. Similarly, the main effect of the prize offered on the degree of understanding of the program's rules was also significant $(F(1.138)=$ $64.20, p=0.00$ ). On the other hand, the effect of interaction between the regulatory focus and the prize offered on the degree of understanding of the program's rules was not significant $(F(1.138)$ $=0.27, p=0.61$ ).

Figure 3 below shows the averages of the understanding of loyalty program's rules for each group.

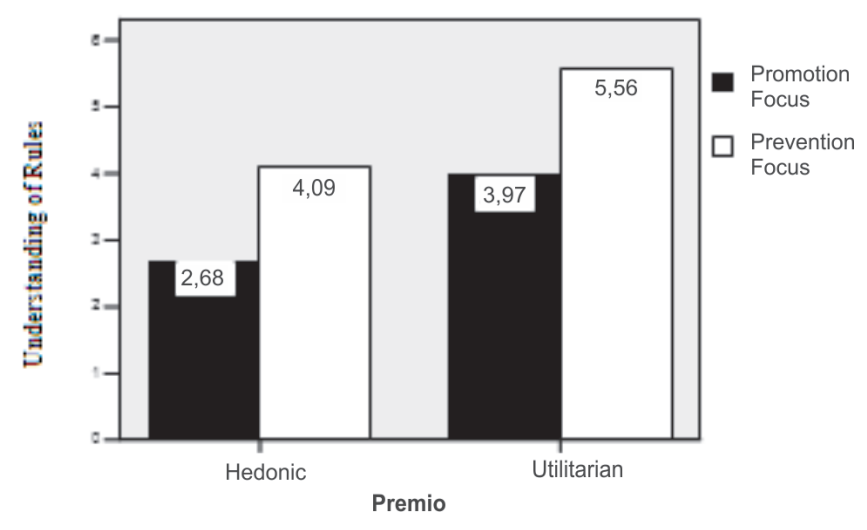

FIGURE 3 - Understanding of rules $\boldsymbol{v}$ s. Regulatory focus and Prize type

Source: the authors, data collection 2012.

The average understanding of the rules shown by the participants when the prize offered is of the hedonic type (left side of the figure) is 
smaller for the group in the promotion scenario in comparison to the group in the prevention scenario $\left(M_{\text {Promotion }}=2.68\right.$ vs. $\left.M_{\text {Prevention }}=4.09\right)$. Similarly, the average understanding of the rules shown by the participants when the prize offered is of the utilitarian type (right side of the figure) is smaller for the group in the promotion scenario in comparison to the group in the prevention scenario $\left(M_{\text {Promotion }}=3.97\right.$ vs. $\left.M_{\text {Prevention }}=5.56\right)$.

When comparing the groups which were allocated to different loyalty program scenarios, the respondents of the prevention scenario showed higher averages of understanding of the loyalty program's rules when the prize offered was of the utilitarian type, against the situation in which the prize offered was of the hedonic type ( $M_{\text {Utilitarian }}$ $=5.56$ vs. $\left.M_{\text {Hedonic }}=4.09\right)$. Similarly, the average understanding of the rules was also higher when the prize offered was of the utilitarian type, and the respondents were allocated to the promotion scenario, in comparison to the offer of a hedonic prize $\left(M_{\text {Utilitarian }}=3.97\right.$ vs. $\left.M_{\text {Hedonic }}=2.68\right)$.

This result allowed us to corroborate the hypothesis that both the regulatory focus and the type of prize offered by a loyalty program will affect the understanding of the program's rules. However, it does not corroborate the hypothesis that the interaction between the regulatory focus and the type of prize offered would also affect the understanding of the rules shown by the study participants. This fact can be explained by the types of prizes chosen to represent the hedonic prizes (popcorn and soda combo, and thermal bag), and the utilitarian prizes (bonus to purchase a second ticket, and bonus to use the gas stations services or products) that could have been interpreted contrary to the research purpose. This issue was not checked in this study, and is therefore suggested as a topic for future researches.

Even though, we can conclude that the understanding of participation rules will be higher for the individuals in the prevention scenario, and also for those receiving utilitarian prizes in loyalty programs.

\section{CONCLUSIONS AND IMPLICATIONS}

This study presents two main theoretical implications: the influence of the regulatory focus of loyalty programs on the understanding of these programs' rules, and the influence of the type of prize offered by the loyalty program on the understanding of these programs' rules.

Three experiments were conducted with the following designs: Experiment $1-2$ (regulatory focus: promotion vs. prevention) by 1 (understanding of rules) between subjects, with a sample of 69 participants; Experiment $2-2$ (type of prize: hedonic vs. utilitarian) by 1 (understanding of rules) between subjects, with a sample of 117 participants; and Experiment 3-2 (regulatory focus: promotion $v s$. prevention) by 2 (type of prize: hedonic vs. utilitarian) between subjects, with a sample of 142 participants.

Experiment 1 provided support to evidence the first hypotheses proposed in this study. Thus, corroborating the $\mathrm{H}_{1 \mathrm{a}}$ and $\mathrm{H}_{1 \mathrm{~b}}$, hypotheses, the participants who were allocated to the prevention scenario showed a higher degree of understanding of the loyalty program's rules, than those who were allocated to the promotion scenario. Experiment 2 also allowed us to corroborate the next hypotheses proposed in this study $\left(\mathrm{H}_{2 \mathrm{a}}\right.$ and $\left.\mathrm{H}_{2 \mathrm{~b}}\right)$. Therefore, it was evidenced that similarly to the way the regulatory focus adopted by the loyalty program influenced the degree of understanding of the loyalty programs' rules shown by the study participants, the type of prize did the same, so that the respondents who received the utilitarian prize showed a higher degree of understanding of the loyalty programs' rules than the respondents who received the hedonic prize. The Experiment 3 showed that the pertinence of the results found in previous experiments though didn't served to confirm the hypothesis that the interaction effect between the regulatory focus and the type of prize offered would also influence the degree of understanding of the loyalty programs' rules $\left(\mathrm{H}_{3}\right)$. Thus, once again it was observed that the respondents that were allocated to the prevention scenario or who received the utilitarian prize showed a higher degree of understanding of the 
loyalty programs' rules, with this result not being affected by the compatibility or incompatibility of the regulatory focus and the type of prize offered by the program.

The main theoretical contributions suggested in this study are that, firstly, the hypothesis that the individuals in the prevention state will act in an "alert" way, while those individuals in the promotion state will do it in the "eager" way, suggested by Förster, Higgins and Bianco (2003), and Pham and Avnet (2004), was confirmed in the loyalty programs scenario, in which those induced by the program description to adopt a prevention attitude showed a higher degree of understanding the rules, than those induced to adopt a promotion attitude. Secondly, the hypothesis that under the promotion focus the attributes related to hedonic and aspirational benefits, represented by the hedonic prizes offered in the loyalty programs, will have a bigger evaluating weight on the promotion focus, while the attributes related to utilitarian and necessity benefits, represented by utilitarian prizes offered by the loyalty programs, will have a bigger evaluating weight on the prevention focus, as suggested by Aaker and Lee (2001), and Wang and Lee (2006), was also confirmed in this study. Finally, the last hypothesis of this research, that there would be an effect of compatibility between the regulatory focus and the type of prize offered by it, and that this effect would positively affect the evaluation of the loyalty programs' rules understanding, was not corroborated. An alternative explanation that was not tested in this study, and which is suggested for further research, is that the types of prizes offered might suggest both hedonic and utilitarian propensities, and thus these should be very different and pretested to meet the desired effects. Furthermore, the evaluation of loyalty programs' participation rules implies losses versus no losses in such programs, characteristics predominantly present in the prevention state (SHAH, HIGGINS, FRIEDMAN, 1998; ZHOU, PHAM, 2004; LEE, AAKER, 2004). Thus, we suggest that the testing of other evaluations in loyalty programs, such as the willingness to redeem prizes, to attain the score, or the willingness to enter such programs, represents measures less associative to such characteristics.

As managerial contributions, we suggest that a loyalty program that represent a way to attain "progresses" and "concretizations" (promotional regulatory focus) in the mind of consumers offers opportunities to obtain prizes related to dreams, aspirations and aesthetic aspects of the consumptions (hedonic prizes) for the program's members. Following the same idea, a loyalty program that represents a way of attaining "security" and "protection" (regulatory focus of prevention) in the mind of consumers should offer guarantees of attaining prizes related to convenience, economy and tangible attributes (utilitarian prizes) for the program members, based on the information presented. In addition to this importance guidance, we highlight the role of explaining the accumulation and the redemption of points rules in loyalty program, which many times serve as a discouraging factor for the consumer's participation in such programs. Based on the results found in this work, we suggest that the loyalty programs' rules are clear and objective in any loyalty program scenario, either with a promotion focus or a prevention one, but mainly for loyalty programs that stand out for providing "progress" and "concretization" objectives (promotion regulatory focus), because, as herein observed, the participants allocated to the promotion scenario showed a lower degree of understanding of the loyalty programs' rules, which, in an actual situation, could result in discouraging those consumers to enter and act in such programs.

As for the limitations found in the experiments conducted in this work, we highlight the use of a small scale sample, in the first experiment, which made the conduction of more complex statistical analyses impossible, as well as to separate individuals in a higher number of experimental groups. Furthermore, other evaluation measures were not included in the analyses, which could have jointly affected the answers of participants in this study. At last, a logical consequence of the loyalty programs 
evaluation process, the intention to enter the program, was also not checked.

Suggestions for further research are divided into two scopes: the inclusion of more measures of evaluation of loyalty programs, and of the intention to enter the loyalty programs after such evaluations. Thus we suggest, for instance, measures of the willingness to obtain score or to redeem prizes should jointly influence the evaluation of loyalty programs by the participants, and such measures should result in the propensity to enter such programs.

\section{REFERENCES}

AAKER, J.; LEE, A. Y. "I" seek pleasures and "we" avoid pains: the role of self-regulatory goals in information processing and persuasion. Journal of Consumer Research, Chicago, v. 28, n. 1, p. 33-49, June 2001.

BOOTZIN, R. R. et al. Psychology today. New York: McGraw Hill, 1991.

BRETZKE CONSULTORIA. Sistema de fidelização: como encantar seu cliente. 2005. Disponível em: <http://www.bretzke-marketing.com. br/textos/artigos09.htm>. Acesso em: 2 out. 2011.

CESARIO, J.; GRANT, H.; HIGGINS, E. T. Regulatory fit and persuasion: transfer from "feeling right". Journal of Personality and Social Psychology, Washington, D.C., v. 86, n. 3, p. 388-404, Mar. 2004.

DREZÈ, X.; HOCH, S. J. Exploiting the installed base using cross-merchandising and category destination programs. International Journal of Research in Marketing, Amsterdam, v. 15, n. 5, p. 459-471, Dec. 1998.

FÖRSTER, J.; HIGGINS, E. T.; BIANCO, A. T. Speed/accuracy decisions in task performance: Built-in trade-off or separate strategic concerns? Organizational Behavior and Human Decision Processes, San Diego, v. 90, n. 1, p. 148-164, Jan. 2003.
GOODWIN, C. J. Research in Psychology: methods and design. 5th ed. New York: J. Wiley, 2007.

HIGGINS, E. T. Beyond pleasure and pain. American Psychologist, Washington, D.C, v. 52, n. 12, p. 1280-1300, Dec. 1997.

How self-regulation creates distinct values: the case of promotion and prevention in decisionmaking. Journal of Consumer Psychology, Mahwah, v. 12, n. 3, p. 177-191, 2002.

Making a good decision: value from fit. American Psychologist, Washington, D.C, v. 55 , n. 11, p. 1217-1230, Nov. 2000.

Promotion and prevention: regulatory focus as a motivational principle. Advances in Experimental Social Psychology, [S.1.], v. 30, p. $1-46,1998$.

Self-discrepancy: a theory relating self and affect. Psychological Review, Washington, D.C, v. 94, n. 3, p. 319-340, July 1987.

HIRSCHMAN, E.; HOLBROOK, M. B. Hedonic consumption: emerging concepts methods and propositions. Journal of Marketing, Binghamton, v. 46, n. 3, p. 92-102, 1982.

HSEE, C. K. et al. Medium maximization. Journal of Consumer Research, Chicago, v. 30, n. 1, p. 1-14, June 2003.

KEPPEL, G.; WICKENS, T. D. Design and analysis: a researcher's handbook. New Jersey: Prentice Hall, 2004.

KIVETZ, R.; SIMONSON, I. Self control for the righteous: toward a theory of pre-commitment to indulgence. Journal of Consumer Research, Chicago, n. 29, n. 2, p. 199-217, Sept. 2002a.

; _ Earning the right to indulge: effort as a determinant of customer preferences toward frequency program prizes. Journal of Marketing Research, Chicago, v. 39, n. 2, p. 155-170, May 2002b. 
LEE, A. Y.; AAKER, J. L. Bringing the frame into focus: the influence of regulatory fit on processing fluency and persuasion. Journal of Personality and Social Psychology, Washington, D.C., v. 86, n. 2, p. 205-218, Feb. 2004.

LEWIS, M. The influence of loyalty programs and short-term promotions on customer retention. Journal of Marketing Research, Chicago, v. 41, n. 3, p. 281-292, Aug. 2004.

NUNES, J. C.; DRÈZE, X. Your Loyalty program is betraying you. Harvard Business Review, Boston, v. 84, n. 4, p. 124-131, 2006.

O'BRIEN, L.; JONES, C. Do prizes really create loyalty? Harvard Business Review, Boston, v. 73, p. 75-82, May/June 1995.

PHAM, M. T.; AVNET, T. Ideals and oughts and the reliance on affect versus substance in persuasion. Journal of Consumer Research, Chicago, v. 30, n. 4, p. 503-518, Mar. 2004.

; HIGGINS, E. T. Promotion and prevention in consumer decision making: state of the art and theoretical propositions. In: RATNESHWAR, S.; MICK, D. G. (Eds.). Inside consumption: consumer motives, goals and desires. Routledge: New Jersey, 2005. p. 8-46.

ROTTENSTREICH, Y.; HSEE, C. K. Money, kisses, and electric shocks: on the affective psychology of risk. Psychological Science, Malden, v. 12, n. 3, p. 185-190, 2001.

SAFER, D. A. Preference for luxurious or reliable products: promotion and prevention focus as moderator. Unpublished dissertation, Columbia University, NY, 1998. Disponível em: < http://books.google.ca/books/about/ Preferences_for_Luxurious_Or_Reliable_ Pr.html?id=O6wRnQEACAAJ\&redir_esc $=y$ >. Acesso em: 2 out. 2011.

SCHWARZ, N.; CLORE, G. L. Mood, misattribution and judgments of well-beinginformative and directive functions of affective states. Journal of Personality and Social Psychology, Washington, D.C., v. 45, n. 3, p. 513-523, 1983.

SHADISH, W. R.; COOK, T. D.; CAMPBELL, D. T. Experimental and quasi-experimental designs for generalized causal inference. Boston: Houghton Mifflin Company, 2002.

SHAH, J. Y.; HIGGINS, E. T.; FRIEDMAN, R. S. Performance incentives and means: How regulatory focus influences goal attainment. Journal of Personality and Social Psychology, Washington, D. C., v. 74, n. 2, p. 285-293, Feb. 1998.

SHARP, B.; SHARP, A. Loyalty programs and their impact on repeat-purchase loyalty patterns. International Journal of Research in Marketing, Amsterdam, v. 14, n. 5, p. 473-486, Dec. 1997.

SOMAN, D. The illusion of delayed incentives: evaluating future effort-money transactions. Journal of Marketing Research, Chicago, v. 35, n. 4, p. 427-437, Nov. 1998.

SPIEGEL, S.; GRANT-PILLOW, H.; HIGGINS, E. T. How regulatory fit enhances motivational strength during goal pursuit. European Journal of Social Psychology, Chichester, v. 34, n. 1, p. 39-54, Jan./Feb. 2004.

STRAHILEVITZ, M.; MYERS, J. G. Donation to charity as purchase incentives: how well they work may depend on what you are trying to sell. Journal of Consumer Research, Chicago, v. 24, n. 4, p. 434-446, 1998.

WANG, J.; LEE, A. Y. The role of regulatory focus in preference construction. Journal of Marketing Research, Chicago, v. 43, n. 1, p. 28-38, Feb. 2006.

ZHOU, R.; PHAM, M. T. Promotion and prevention across mental accounts: when financial products dictate consumer's investments goals. Journal of Consumer Research, Chicago, v. 31, n. 1, p. 125-135, June 2004. 